\title{
A BALÁNBÁNYAI RÉZÉRC (KALKOPIRIT) FELHASZNÁLHATÓSÁGÁNAK KÉRDÉSEI A BRONZKORI ESZKÖZÖK ELŐÁLLÍTÁSÁBAN
}

\section{ISSUES OF THE USABILITY OF COPPER ORE (CHALCOPYRITE) FROM BĂLAN FOR USTENSILES PRODUCTION IN THE BRONZE AGE}

\author{
Márton László ${ }^{1}$, Talpas János ${ }^{2}$, Bitay Enikő ${ }^{3}$ \\ ${ }^{1}$ Erdélyi Múzeum-Egyesület, Müszaki Tudományok Szakosztálya, Kolozsvár, 400009 \\ Cluj-Napoca, str. Napoca nr. 2-4, martonlb@yahoo.com \\ ${ }^{2}$ Babeş-Bolyai Tudományegyetem, Kolozsvár, 400006 Cluj-Napoca, str. Clinicilor \\ nr.5-7.talpasjanos@gmail.com \\ ${ }^{3}$ Sapientia Erdélyi Magyar Tudományegyetem, Marosvásárhelyi Kar, 540485
Romania, Marosvásárhely/Târgu-Mureş, OP 9, CP 4, Tel.+40-751-016063,
ebitay@ms.sapientia.ro
}

\begin{abstract}
Archaeological publications connect the raw material used for the production of the copper and bronze artifacts discovered during the excavations carried on in Szeklerland to the use of the chalcopyrite from the Bălan copper ore deposit. For now, this assumption is not confirmed by concrete evidence. Men of the Bronze Age can't possibly have had knowledge on the metallurgy of sulphide-type copper ores like chalcopyrite. Applying investigations based on spectroscopy, the Bronze Age use of the chalcopyrite from Bălan could be either confirmed or infirmed, the new data throwing more light on the provenance of the bronze artifacts discovered_in the Szeklerland.
\end{abstract}

Keywords: copper ore from Bălan, chalcopyrite, ancient artifacts, copper ore composition, trace element content of copper ore and bronze, scientific methods in archaeology.

\section{Összefoglalás}

A székelyföldi régészeti ásatások réz és bronz tárgyainak előállításában felhasznált nyersanyagot, a rézércet, a balánbányai kalkopirit felhasználásához kapcsolja a szakirodalom. Ez csupán a feltételezés kategóriájába sorolható, nincs erre kézzelfogható bizonyíték. A bronzkor embere nem tudhatta a szulfid típusú rézércek, mint amilyen a kalkopirit, kohászati feldolgozásának technológiáját. Természettudományos módszerek alkalmazásával, a spektroszkópia lehetőségeinek felhasználásával bizonyítani, vagy cáfolni lehet a balánbányai kalkopirit bronzkori felhasználását, ami új adatokkal, új megvilágításba helyezné a székelyföldi bronzleletek nyersanyagának eredetét.

Kulcsszavak: balánbányai rézérc, kalkopirit, ásatag bronztárgyak, rézérc összetétele, nyomelemek a rézércben és az ötvözetben, természettudományos módszerek a régészetben 


\section{Bevezető}

A székelyföldi régészeti ásatások számos rézkori és bronzkori lelettel gazdagították a múzeumok kiállítási anyagát, segítve a szakembereket a történelmi korok helyhez szabott behatárolásában.

A feltárt leletek között a helyi réz és bronzkor fémből készült tárgyai, eszközei szerszámai, ékszerei is megjelennek a nagy mennyiségü kerámia töredékek társaságában. Ezek tipológiai beazonosítása a régészet feladata, de egy meghatározott történelmi korszakon belül is lehetnek helyi jellegzetességek. Ritkább az a szerencsés eset, amelyben az ásatag réz, vagy bronztárgy környezetében ezek gyártására utaló olvasztókemence maradványok, kohászati salak, netán öntőforma töredékek is fellelhetők. Ezek is jellemzik a kort, amelyben készültek, segítik a keltezés lehetőségét.

A természettudományos módszerek alkalmazása a régészeti leletek tanulmányozásában nem újdonság a régmúlt időket kutató tudományok müvelőinek. A vegyi elemzések, mikroszkópia, spektroszkópia, a 14-es szén izotópia adta lehetőségek alkalmazása jelentős többletinformációval segítik a kiértékelő régészeti munkát.

\section{A réz- és bronzművesség kezdetei Székelyföldön}

A rézmüvesség kezdetei a rezet tartalmazó ércek természetes lelöhelyeihez kapcsolhatók. Jó néhány elmélet érvel arról, hogy a rézmüvesség (rézöntés) kifejlődése több helyszínen, egymástól függetlenül is létre jöhetett. "Érckutatók kellett, hogy bevezessék az olvasztás és öntés tudnivalóit, de úgy tünik, hogy az erdélyi termékek helyi rézből készültek." (C. Renfrew) [1] Az erdélyi rézkor rézmüvessége részeként kell értékelnünk a székelyföldi rézmüvességet.

A székelyföldi rézmüvesség nyersanyag bázisa nem tisztázott, de nem kizárt, hogy a
Csíkszentdomokos - Balánbánya határában található komplex rézérc is lehetett. Részletes helyszíni feltárások hiányában a székelyföldi rézkori leletek nem nyújtanak átfogó és reális képet a kor rézmüvességéröl, különösképpen arról nem, hogy a leletek valóban a csíkszentdomokos balánbányai vonulat rézércéből készültek. Ennek tisztázása, pontosítása lehetséges természettudományos módszerekkel. A réztárgy anyagának elemi összetételét meg lehet határozni például spektroszkópos vizsgálatokkal. A tellúr vagy más elemek jelenléte, koncentrációja a réztárgy anyagában fontos információ lehet a rézérc balánbányai, esetleg más erdélyi rézérc lelőhelyről való eredetéről. Ismeretes, hogy bizonyos rézércek, ide tartozik a balánbányai kalkopirit is, színképelemzés útján meghatározható koncentrációban tartalmaznak tellúrt. A tellúr egyedivé tesz minden olyan rézércet, amely ezt az elemet is tartalmazza. [2]

A tellúr jelenlétének, koncentrációjának meghatározásával, valamint más, szennyező összetevőként jelen lévő elemek kimutatásával értékelhető pontossággal meghatározható az illető bronztárgy alapanyagának eredete. Ehhez előzetesen ismerni kell a feltételezett eredetü rézérc összetételét. Ezt napjainkban a metallográfia tudománya rutinelemzésként kezeli. A természettudományos módszerek minél szélesebb körü alkalmazása a régészetben új utakat nyithat a letünt évszázadok fémmüvességének megismeréséhez.

Az 1. táblázat néhány székelyföldi régészeti ásatás rézből készült leleteit, ezek lelőhelyét foglalja össze, a teljesség igénye nélkül. A leletek az i.e. 4. évezred utolsó századaiból származó réztárgyak.

$\mathrm{Az}$ 1. ábra a sepsiszentgyörgyi Székely Nemzeti Múzeum gyüjteményének néhány ásatag bronztárgyát mutatja be. 
Az, hogy e leletek nyersanyaga a csíkszentdomokosi-balánbányai rézérc lelőhelyekhez is kapcsolható, egyelöre csupán feltételezés, ugyanis az itt végzett régészeti kutatások nem bizonyították a rézérc bányászatának őskori nyomait, netán a rézérc kohósítását. Azt is meg kell jegyeznünk, hogy az említett terület archeológiai feltárása sem teljes. Colin Renfrew leszögezi: "Afelöl kétségünk sem lehet, hogy a felhasznált réz helyi eredetű volt." [1] További kutatásokra van szükség, természettudományos módszerek bevonásával kell azonban tisztázni, hogy ezt a rézlelöhelyet egyáltalán felhasználta-e az őskor rézmüve-

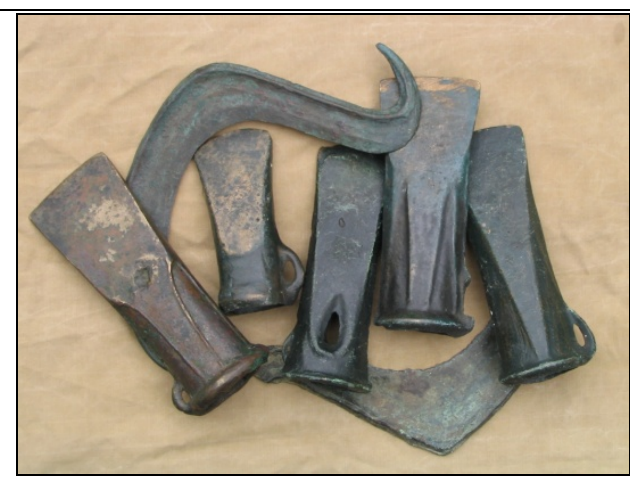

1. ábra. Ásatag bronztárgyak. A Székely Nemzeti Múzeum (Sepsiszentgyörgy) tulajdona se.

1. táblázat. Néhány székelyföldi régészeti ásatás rézkori, rézböl készült lelete

\begin{tabular}{|c|c|c|}
\hline \multicolumn{3}{|c|}{ RÉZKOR } \\
\hline Lelöhely & Lelet & Megjegyzések \\
\hline \multirow[t]{2}{*}{ Erösd (CV) } & $\begin{array}{l}\text { vörös rézhuzal töredékek, } \\
\text { kéthegyü vékony rézár, } \\
\text { huzalból készült kis karikák }\end{array}$ & $\begin{array}{l}\text { Több ásatási rétegből származnak más } \\
\text { hasonló lelettel, kerámia töredékkel. }\end{array}$ \\
\hline & $\begin{array}{l}\text { kettős, ellentétes élü rézcsá- } \\
\text { kány }\end{array}$ & $\begin{array}{l}\text { A kőkorszak és a bronzkorszak közötti } \\
\text { átmeneti időkbőll. }\end{array}$ \\
\hline $\begin{array}{l}\text { Gyergyószentmiklós } \\
\text { (HR) }\end{array}$ & $\begin{array}{l}\text { egyélű rézcsákány, más kilenc } \\
\text { darabbal együtt }\end{array}$ & $\begin{array}{l}\text { A Lázár grófok birtokán lelték, pontos } \\
\text { helye ismeretlen. }\end{array}$ \\
\hline Árkos (CV) & két fejszéböl álló lelet & \\
\hline Sáromberke (MS) & nyéllyuk-nyúlványos balta & $\begin{array}{l}\text { Hasonló baltákat leltek Nyárádgálfalván, } \\
\text { Altorján, Kovásznán, Sepsibesenyőn, Szé- } \\
\text { kelyzsomboron. }\end{array}$ \\
\hline $\begin{array}{l}\text { Várhegy (HR) } \\
\text { Albis (CV) } \\
\text { Bodok (CV) } \\
\text { Csernáton (CV) } \\
\text { Székelyudvarhely (HR) }\end{array}$ & $\begin{array}{l}\text { kettős ellentétes élü rézcsáká- } \\
\text { nyok }\end{array}$ & $\begin{array}{l}\text { Ezek már a kezdeti bronzkor időszakából } \\
\text { származnak. }\end{array}$ \\
\hline Csíkdánfalva (HR) & rézcsákány & $\begin{array}{l}\text { Magángyüjteményben, különleges kikép- } \\
\text { zésű fokkal. }\end{array}$ \\
\hline Sepsibesenyő (CV) & rézfokos & Az egyetlen székelyföldi példány. \\
\hline
\end{tabular}

Első réztárgyait a kor embere, termésrézből [3] készítette. Tetszetős színe értékessé tette az addig csupán bőrből, csontból, fából készült, főleg dísztárgyakkal, egyszerü ékszerekkel szemben.
A kalapálásos hidegalakítás volt az első technológiai művelete a termésréz feldolgozásának. Az őskor rézmüvese megtanulta, hogy a vörös színű fém könnyen alakítható kalapálással, ugyanakkor az ütések hatására keménnyé, rideggé válik, ami megnehezíti a 
további alakváltoztatást. Azt is kitalálta, hogy felmelegítéssel a rideg, törékeny réztárgy ismét meglágyul, további alakításra is alkalmassá válik

Hosszú századoknak kellett eltelniük, amíg a mesterségbeli tudás gyarapodása meghozta eredményét, a rézércben található fém kinyerését olvasztással.

A kezdetekkor erre csak bizonyos rézércek mutatkoztak alkalmasoknak. Ma már világos, hogy ezek az ércek rézoxidok, rézkarbonátok voltak, amelyek könnyebben redukálhatók [4], mint például a szulfid típusú rézércek.

$\mathrm{Az}$ oxidos, karbonátos rézércek: a kuprit, $\mathrm{Cu}_{2} \mathrm{O}$, azurit, $2 \mathrm{CuCO}_{3} \cdot \mathrm{Cu}\left(\mathrm{OH}_{2}\right)$, malachit, $\mathrm{CuCO}_{3} \cdot \mathrm{Cu}(\mathrm{OH})_{2}$ a tüzelőanyaggal való hevítéskor aránylag könnyen redukálódó ércek. Égése közben a faszén a szükséges hőt és a redukáló közeget is biztosítja. A $700^{\circ} \mathrm{C}$ körüli hőmérsékleten a következő vegyi reakció megy végbe:

$$
\begin{aligned}
& \mathrm{CuO}+\mathrm{C}=\mathrm{Cu}+\mathrm{CO} \\
& \mathrm{CuO}+\mathrm{CO}=\mathrm{Cu}+\mathrm{CO}
\end{aligned}
$$

A folyamatban még nem keletkezik vörösréz, mert a réz olvadási hőmérséklete $1084^{\circ} \mathrm{C}$. A rézmüvesség megjelenésének kezdetén fontos szerepe volt a fazekasságnak. A kerámiagyártásban használatos kemencék hőmérséklete $600-700^{\circ} \mathrm{C}$-ot érhetett el, ami már a rézérc-olvasztás előcsarnoka lehetett. A fújtató, a többletlevegő befúvásával létrehozott hőmérséklet-emelés szerepe valóságos ugrást jelentett általában az ércek feldolgozásában, nem csak a rézércek esetében.

A balánbányai rézérc, a kalkopirit $\left(\mathrm{CuFeS}_{2}\right)$ szulfid típusú érc. amelynek pirotechnikai feldolgozása őskori módszerekkel szinte lehetetlen volt. A kalkopirit feldolgozásának alapja szintén redukciós folyamat. A folyamat részeredményeként az égést tápláló oxigén egy részének kénnel való reakciójában a végtermék a kéndioxid, ami az égési gázok összetevőjeként távozik a kemencéből. A megmaradt részből a vasnak szintén az oxigénnel való reakciója követ- keztében vasoxid keletkezik, ami a salaknak egyik összetevője lesz. De ez a folyamat nem ilyen egyszerü, mert a kvarchomok folyamatos adagolásával, a vasszulfiddal vegyi reakcióba lép a következő vegyi reakció szerint:

$$
2 \mathrm{FeS}+3 \mathrm{O}_{2}+\mathrm{SiO}_{2}=2 \mathrm{FeOSiO}_{2}+\mathrm{SO}_{2}
$$

Tulajdonképpen ez az első salakképző folyamat. Mivel a salak könnyebb a rézben dúsult olvadéknál, a felszínen összegyül, és el lehet távolítani az olvadékról. A megmaradt rézszulfid (CuS) olvadék a további levegő befújás következtében redukálódik:

$$
\mathrm{CuS}+\mathrm{O}_{2}=\mathrm{SO}_{2}+\mathrm{Cu}
$$

$\mathrm{Ez}$ a vegyi reakció két lépésben megy végbe. Először a rézoxid és a rézszulfid szenved részleges redukciót. A maradék rézszulfidnak rézoxiddal való reakciójából keletkezik a fémes réz.

$2 \mathrm{Cu}_{2} \mathrm{O}+\mathrm{Cu}_{2} \mathrm{~S}=\mathrm{SO}_{2}+6 \mathrm{Cu}$

A vas olvadáspontja (1535 $\mathrm{C}^{\circ}$ ) jóval magasabb a réz olvadáspontjánál, ezért az érc vastartalma a salak összetevője marad. Ezért tartalmaznak a szulfid típusú rézércek salakjai vasoxidot.

Hogyan találta ki az őskor embere a réz kinyerését érceiből i.e. 4500 évvel?

Mint előbb megjegyeztük, a rézmüvesség az újkőkor második felében, a festett kerámiával egy korban keletkezett. A kerámiagyártásnak (az agyag feldolgozásának) akkor már évezredes múltja volt, viszonylag jól kidolgozott technológiájaval. A kor fazekasműhelyei jó néhány típusú égetőkemencét üzemeltettek.

A kőböl épült, agyaggal kitapasztott égetőkemence lehetett a réz ércéből való kinyerésének kiinduló pontja. Feltehetőleg az égetőkemence építésekor falazatába rezet tartalmazó kő is bekerülhetett, olyan rézérc, aminek fémtartalma az őskor embere számára a kezdetekkor ismeretlen volt, hiszen maga a fém is ismeretlen volt abban a korban.

Az edényégető kemence többszöri használata a falazat többszöri felhevülésével járt, így a réztartalmú kőben végbementek 
azok a folyamatok, amelyek a későbbiekben az érc pörkölését, olvasztását, a fém-réz (színréz) kinyerésének folyamatát jelentették a rézércek kohósításában. Ezt nevezhetjük a rézmüvesség igazi kezdetének, amikor a kor emberének meg kellett találnia azt a követ, amelyik rezet tartalmaz, de nem csupán natív rezet. Ez után a kemény sziklából, kőből készített szerszámaival ki kellet fejtenie azt a réteget, amelyik színével, netán természetes natív réz tartalmával kivált környezetéből. Iszonyú nehéz munka lehetett. Az egész folyamat a bányászástól az olvasztáson át a kinyert réz feldolgozásának elsajátításáig hosszú évszázadokon át tökéletesedett és lassan terjedt az őskorban. És ha a kor embere már tudatosan kereste a felszínen található termésrezet is tartalmazó követ, tapasztalatot is szerzett azzal kapcsolatosan, hogy a megolvadt fém az égetőkemence falában található rézérc terméke. Bele is folyhatott valamelyik edényébe. Ez vezethette arra a felfedezésre, hogy egyes, rezet tartalmazó kövek agyagedényben is megolvaszthatók, és hogy a megdermedt, megszilárdult fém felveszi az edény belső formáját. Ez lehetett az a lépés, amely elvezette az embert az öntőforma elkészítéséhez, ami az igazi fém öntészet kezdetét jelentette.

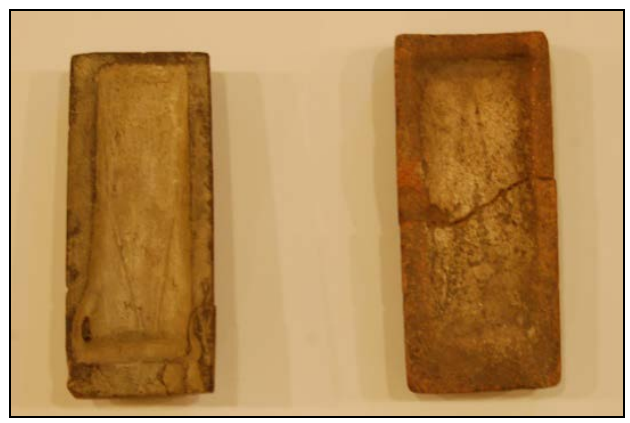

2. ábra. Öntőforma. Székely Nemzeti Múzeum, Sepsiszentgyörgy tulajdona
A kétrészes öntőforma használata volt a fémmüvesség következő állomása, amely már bonyolult alakú végtermékek előállítását is lehetővé tette.

A Székelyföld területén végzett ásatások alkalmával öntőforma maradványai is elökerültek (2., 3. ábra).

Az igazi, korszakalkotó ugrást a fémművességben az ötvözés gyakorlata jelentette. I.e. 2500 körül a rézhez egy másik, alacsonyabb olvadási hőmérsékletű fémet olvasztottak. A két fém keveredéséből, keletkezett az új, korszakalkotó fémötvözet, a bronz. Ennek, az új fémnek az emberi civilizációra és kultúrára gyakorolt hatása egy új, történelmi kort is kialakított, a bronzkort.

$\mathrm{Az}$ őskor rézmüvességének története a Közel-Keleten és Dél-Kelet Európában kezdődhetett (kőrézkor, i.e. 3500-4500). Ezt a történetet összegezve megállapítjuk, hogy ebben a korban alakult ki a következő évezredek fémmüvességének mesterségbeli alaptudása. A fejlődés néhány szakasza véletlenszerü, a folytatás viszont logikus és egyre tudatosabb folyamattá alakult az évezredek folyamán.

"A bronzkor szerves folytatása a már említett aeneolitikus, illetőleg rézkori periódusnak, ennek alapján a fokról-fokra fejlődést, mint általában Erdélyben, a Székelyföldön is nyomon kellene követnünk." (Roska Márton). [5]

A Székelyföld területén végzett ásatások alkalmával előkerült nagyszámú bronz leletből néhányat a 2 . táblázat foglal össze.

A leletek nagy száma a bronzmüvesség magas szintjéről, öntőműhelyek működéséről tanúskodnak, néhol egykori nyersanyag és késztermék raktárakra utalnak (Felsőcsernáton, Bánkfalva [3]), mindez i.e. 3000-3500-ben. 


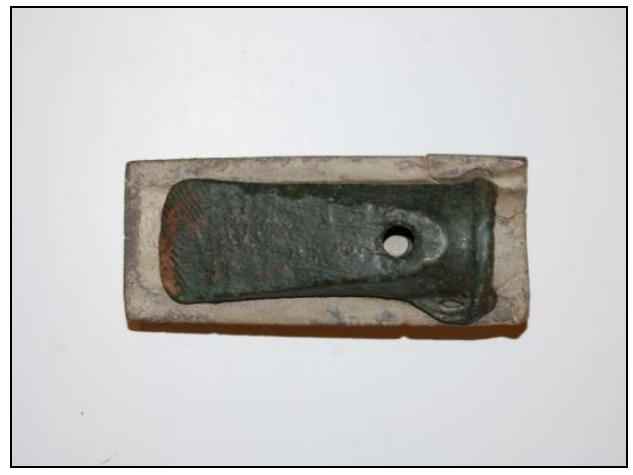

3. ábra. Öntőforma és terméke. Székely Nemzeti Múzeum, Sepsiszentgyörgy

Mit tudtak, milyen technológiai tapasztalat halmozódhatott fel ahhoz, hogy Erdély, és ezen belül a székelyföldi rész híressé váljon bronzmüvességéről?

Az őskor mestere ismerte a használható, rezet tartalmazó ásványi érceket. Tudott olvasztókemencét építeni, agyag és porrá tört kerámia keverékéből olvasztótégelyt készíteni. Tudott faszenet égetni és a szenet felhasználni olvasztókemencéjének fütésében. Tudott huzatos égőteret létrehozni, amivel növelhette az olvasztási folyamat hőmérsékletét. Ismerte az ón tulajdonságait, szerepét, jelentőségét abban a keverékben, aminek tudatos előállítású végtermékeként új fémötvözet, a bronz keletkezett. Megtanulta az ötvözőelem részarányának jelentőségét, és a bronz rendeltetésének függvényében elő tudott állítani jellegzetes összetételü, különböző tulajdonságú bronz ötvözeteket ékszerek (fibulák, karkötők), használati tárgyak (balták kések, sarlók), harcászati eszközök (dárdák, kardok, harci szekercék, 4. ábra) számára.

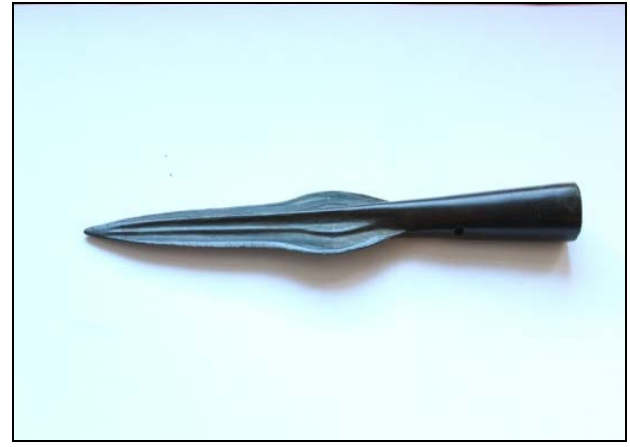

4. ábra. Bronz dárdahegy. Székely Nemzeti Múzeum, Sepsiszentgyörgy

Meg kell említenünk, hogy a feltárt öntőszerszámok (a Felsőcsernátonban előkerült, agyagból készült öntőkanál töredék, öntőforma töredékek), és a jelentős mennyiségü salakmaradvány a régészek szerint a bronzkort meghatározó összes fejlődési szakasz nyomait magukon viselik, a kezdetektől a kora vaskorba beleolvadva. "A szerszámtípusok görögországi és általában balkáni kapcsolatokra utalnak." [3] A kora vaskor B szakaszában már az új fém, a vas is együtt jelentkezik bronztárgyakkal. Ez a bronzkor végét és a kora vaskor kezdetét jelenti. A viszonylag nagyszámú vasrudacska a bronz öntőminták együttesében a vasfeldolgozásnak a bronzöntés technikájával való együtt fejlődését jelenti, bár a bronztól a vasmüvességig egy évezrednek kellett eltelnie. Az említett korszakban a vasötvözetek hőkezelésének technikája ismeretlen volt.

A bronzkori bronzmüvesség csúcstechnológiáját a viaszveszejtéses formázási és öntési eljárás feltalálása és gyakorlata jelentette. Ezzel a formázási, öntési eljárással már bonyolult alakzatú tárgyakat is elő lehetett állítani. 
2. táblázat. Néhány székelyföldi régészeti ásatás bronzból készült lelete

\begin{tabular}{|c|c|c|}
\hline \multicolumn{3}{|c|}{ BRONZKOR } \\
\hline Helység & Lelet & Megjegyzések \\
\hline Sepsiszentgyörgy (CV) & talpas bronzfejsze & \\
\hline Bölön (CV) & bronz szárnyas fejszék & $\begin{array}{l}\text { Ugyanitt sarló és tokos balta töredékek, } \\
\text { bronzkorong, bronzedény. }\end{array}$ \\
\hline Kézdivásárhely (CV) & tokos füles balták & $\begin{array}{l}\text { Egy félholdasan bevágott szájú baltát a } \\
\text { szakirodalom, mint magyar típust ír le. }\end{array}$ \\
\hline Zágon (CV) & tokos kalapács & Ritkaság számba menő. \\
\hline Málnás (CV) & $\begin{array}{l}\text { bronzsarló (erdélyi típus) } \\
\text { bronzkés }\end{array}$ & $\begin{array}{llll}\text { Hasonló példányok } & \text { kerültek } & \text { elö } \\
\text { Csíkdánfalván (HR). }\end{array}$ \\
\hline Fitos martonos (HR) & bronztőr & $\begin{array}{l}\text { Hasonló lelet Zaboláról (CV) is ismeretes. } \\
\text { Az erdélyi bronzkor legvégén készült. }\end{array}$ \\
\hline Maroshéviz (HR) & tőrpenge töredék, fürész, tör & \\
\hline Bardóc (CV) & bronztőr & $\begin{array}{l}305 \text { mm hosszúságú, rövid kardnak is } \\
\text { megfelel. }\end{array}$ \\
\hline Magyaros (MS) & bronzkard & $\begin{array}{l}920 \text { mm hosszú hasonló lelet Kovásznán is } \\
\text { előkerült. }\end{array}$ \\
\hline $\begin{array}{l}\text { Bardóc (CV) } \\
\text { Marosfelfalu (MS) } \\
\text { Altorja( KV) } \\
\end{array}$ & bronzkard & $\begin{array}{l}\text { Különböző típusú és formájú fegyverek, } \\
\text { bronzfejsze, } 25 \text { gyürű nagyságú aranyle- } \\
\text { mez, bronzüst, bronzsarló. }\end{array}$ \\
\hline Sáromberke (MS) & bronzkard & Görbe alakú pengéje lapos. \\
\hline Nyárádszentanna (MS) & harci csákány & Hasonló lelet Sáromberkén is előfordult. \\
\hline $\begin{array}{l}\text { Mezőbánd (MS) } \\
\text { Kedezér (MS) } \\
\text { Marosfelfalu (MS) }\end{array}$ & $\begin{array}{l}\text { lándzsacsúcs, balták, karpere- } \\
\text { cek, fibulák, övrészletek, kard } \\
\text { töredékek }\end{array}$ & $\begin{array}{l}\text { A lándzsahegy gyakori a székelyföldi } \\
\text { kincsleletekben. Például Zágonban kilenc } \\
\text { darabot találtak. Hasonló leletek Bereck és } \\
\text { Nagygalambfalva leleteiben is megtalálha- } \\
\text { tóak. }\end{array}$ \\
\hline Réty (CV) & bronz karperec & Az anyagot csavarással teszik tetszőbbé. \\
\hline Zágon (CV) & bronz karperec töredék & $\begin{array}{l}\begin{array}{l}\text { Hasonló lelet Bölönböl, Málnásról, } \\
\text { Csíkdánfalváról is előkerült. }\end{array} \\
\end{array}$ \\
\hline Marosfelfalu (MS) & $\begin{array}{l}\text { több példánya a bronz karpe- } \\
\text { recnek }\end{array}$ & Töredékek is találhatók ebben a leletben. \\
\hline Bereck (CV) & bronzbalta, lándzsacsúcsok & \\
\hline Csikdánfalva (HR) & $\begin{array}{l}15 \text { tokos, füles balta, } 10 \text { sarló, } \\
5 \text { karperec, } \\
2 \text { lándzsacsúcs } \\
\end{array}$ & $\begin{array}{l}\text { A lelet öntőműhely maradványaival együtt } \\
\text { képezi a bronzkincset. A sarlók nagy része } \\
\text { erdélyi típus. }\end{array}$ \\
\hline Daróc (HR) & 30 bronzbalta, bronzkard & $\begin{array}{l}\text { A balták a kard körül szabályos körben } \\
\text { voltak elhelyezve. }\end{array}$ \\
\hline Erdőszentgyörgy (MS) & $\begin{array}{l}12 \text { tokos füles balta, tokos } \\
\text { véső,füles kiscsésze, bronztá- } \\
\text { nyérka, bogrács, lószerszám- } \\
\text { dísz }\end{array}$ & $\begin{array}{l}\text { A lelet egyes darabjain vasrozsda foltok } \\
\text { voltak. }\end{array}$ \\
\hline Olasztelek (MS) & $\begin{array}{l}\text { bronz sarló töredék, karperec, } \\
\text { halászhorog }\end{array}$ & Egy nagyobb lelet részei. \\
\hline Csikszentkirály (HR) & $\begin{array}{l}\text { bogrács, csésze, serpenyő, } \\
\text { bronzkarika, i.e. IX század }\end{array}$ & $\begin{array}{l}\text { Ekkor a Székelyföldön is megjelenik a vas } \\
\text { használata (csíkbánkfalvi leletek, a } \\
\text { marosújfelfalusi lelet rozsdafoltokat is } \\
\text { tartalmaz). }\end{array}$ \\
\hline
\end{tabular}


A bronzkori bronzmüvesség csúcstechnológiáját a viaszveszejtéses formázási és öntési eljárás feltalálása és gyakorlata jelentette. Ezzel a formázási, öntési eljárással már bonyolult alakzatú tárgyakat is elő lehetett állítani. Szobrászkodva, méhviaszból elkészítették annak a tárgynak a viaszból készült mását, modelljét, amelyet bronzba akartak önteni. A viasz modellt tehéntrágya és agyag pépes állagú keverékével többször is bekenték, majd szárították. Ezt a müveletet annyiszor megismételték, amíg a felhordott keverékből elég vastag réteg képződött. $\mathrm{Az}$ így nyert, bevonattal ellátott viaszmodellt homokágyba illesztették. A megolvadt fémnek beömlő nyílást, a keletkező gázoknak több apró nyílást fúrtak a kéreg bevonaton.

A folyékony bronz a méhviasz formát megolvasztotta, és az a fém nyomásának és hőmérsékletének hatására a gázkieresztő nyílásokon kifolyt. A viasz helyén maradt üreget a folyékony halmazállapotú bronz kitöltötte, majd megdermedt. A kihülés után a formát széttörték és a bronztárgy, a viaszforma hü mása készen volt.

\section{Következtetések}

A székelyföldi régészeti ásatásokból előkerült réz és bronz tárgyak előállításához felhasznált fém és az ötvöző elem eredete nem bizonyított. Csupán bizonyításra szoruló feltételezés, hogy a rézérc a balánbányai natív réz vagy kalkopirit lehetett, ugyanis ha a rézkor, vagy a bronzkor embere a felszínre kibújt natív rezet talált, miért nem találnak hasonlót Balánbányán a modern kor geológusai?

Egyrészt ismeretes, hogy a kalkopiritböl csak bonyolult, több fázisú technológiai eljárással lehet kivonni a rezet, amit a Kr.e. 3000 - 2500 körül nem tudhattak. Ennek ellenére nem kizárt, hogy a nagy koncentrációjú, szabad szemmel is látható rézércet többszöri hevítéssel és kalapálással rézzé dúsították. Ezt is bizonyítani kell, és lehet is a korszerü természettudományos kutatási módszerek alkalmazásával. Mindaddig, amíg ez nem tisztázódik, fennáll az a lehetőség is, hogy a nyersanyagot (rezet, ónt, ólmot) máshonnan hozták. Ezt is lehet bizonyítani a bronz eszközök pl. a Csernáton határában találtak elemzésével, az eredményt összehasonlítva a balánbányai rézérc összetételével. Az ásatag tárgyaknak ugyanazokat az alkotó elemeket kell tartalmazniuk (nyomokban tellúrt, nikkelt, aranyat, ezüstöt), mint a balánbányai rézérc.

Másrészt az őskori rézmüvesség szempontjából fontos lenne a Székelyföldön gyakori olvasztókemencék eddig feltárt maradványainak, és a környezetükben fellelhető kohászati salaknak vegyi és spektroszkópiás elemzéssel való azonosítása, annak ellenére is, hogy a feltárt kemence maradványok és a salak is vas tartalmú ércek feldolgozására utalnak, még a balánbányai körzetben is.

Mindez azt bizonyítja, hogy ma, amikor az anyag szerkezetének kutatását elősegítő müszerek, berendezések sokasága ismeretes, alkalmazásuk a régészetben is kötelező. Egy régészeti lelet csak akkor válik igazán értékké, ha keletkezésének, felhasználásának körülményeit is feltárja a tudomány és a kultúra számára.

\section{Szakirodalmi hivatkozások}

[1] Renfrew, C.: A civilizáció előtt, Osiris Kiadó, Budapest, 1995, 177 - 204.

[2] Kővári, L.: Erdélyország statisztikája. Első kötet, Kolozsvár 1847, 78 - 94.

[3] Székely, Zs.: Csernáton község régészeti monográfiája, Státus Kiadó, Csíkszereda, 2007, 70 -79.

[4] Dumitrescu, I., Paştiu, I.: Metalurgia metalelor neferoase, Editura Didactică şi Pedagogică, Bucureşti 1969, 117 - 118.

[5] Roska, M.: A Székelyföld öskora. Emlékkönyv a Székely Nemzeti Múzeum 50 éves Jubileumára, Székely Nemzeti Múzeum Kiadása, Sepsiszentgyörgy, 1929, 258 - 326. 